\title{
Geothermal Materials Development
}

Annual Report FY 1991

Lawrence E. Kukacka

December 1991

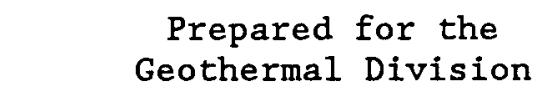

U.S. Department of Energy

1000 Independence Avenue, S.W.

Washington, DC 20585

\section{Energy Efficiency and Conservation Division \\ Department of Applied Science \\ Brookhaven National Laboratory \\ Associated Universities, Inc.}

This work was performed under the auspices of the U.S. Department of Energy, Washington, DC under Contract No. DE-ACO2-76CH00016. 


\section{DISCLAIMER}

This report was prepared as an account of work sponsored by an agency of the United States Government. Neither the United States Government nor any agency Thereof, nor any of their employees, makes any warranty, express or implied, or assumes any legal liability or responsibility for the accuracy, completeness, or usefulness of any information, apparatus, product, or process disclosed, or represents that its use would not infringe privately owned rights. Reference herein to any specific commercial product, process, or service by trade name, trademark, manufacturer, or otherwise does not necessarily constitute or imply its endorsement, recommendation, or favoring by the United States Government or any agency thereof. The views and opinions of authors expressed herein do not necessarily state or reflect those of the United States Government or any agency thereof. 


\section{DISCLAIMER}

Portions of this document may be illegible in electronic image products. Images are produced from the best available original document. 


\section{Executive Summary}

Advances in the development of new materials, the commercial availabilities of which are essential for the attainment of Hydrothermal Category Level I and II Objectives, continue to be made in the Geothermal Materials Deve1opment Project. Many successes have already been accrued and the results used commercially. ${ }^{1}$ In FY 1991, utility company sponsored "full cost" recovery programs based upon materials technology developed in this project were initi. ated on topics such as condensing heat exchangers, high temperature composites for utility vaults used in district heating systems, and corrosion resistant coatings for use in oil-fired electric generating processes.

In FY 1991 the DOE/GD-sponsored R\&D project was focused on reducing well drilling, fluid transport and energy conversion costs. Specific activities being performed included lightweight $\mathrm{CO}_{2}$-resistant well cements, chemical systems for lost circulation control, thermally conductive and scale resistant protective liner systems, corrosion mitigation in process components at The Geysers, and elastomer-metal bonding systems needed for use in high temperature well drilling and safety related applications.

Laboratory testing of BNL-developed phosphate modified calcium aluminate cements confirmed the hydrolytic stability of the materials in $300^{\circ} \mathrm{C}$ brine and their resistance to chemical attack by $\mathrm{CO}_{2}$. Specimens retarded by the addition of borax to make them pumpable by American Petroleum Institute (API) Standards were found to be -20 times more resistant to carbonation than class $\mathrm{H}$ cement and twice as resistant as unmodified calcium aluminate cements. They also meet most of the other API design criteria. Plans to establish a "Cooperative Research and Development Agreement" (CREDA) which will result in further laboratory characterization and downhole testing in several geothermal environments are being formulated.

Similar progress is being made with chemical systems for lost circulation control. If materials placement is to be performed by pumping through an open drillpipe or through a drillable straddle packer, a bentonite-ammonium polyphosphate-borax-magnesium oxide formulation, containing fibers or particulates when large fissures are encountered, can be used. This system was ready for demonstration in FY 1991, but a suitable test site did not become available. Optimization of this and three other formulations for use with other Sandia National Laboratories developed placement technology will be continued in FY 1992.

Work commenced in FY 1991 on the development of high temperature hydrolytically stable chemical coupling systems needed to bond elastomers to metal reinforcement. Until these become available; it will not be possible to produce many important tools needed to reduce well drilling costs. To date very promising results have been achieved using high melting point $\left(>280^{\circ} \mathrm{C}\right)$ polyaromatic-type adhesives. Compared to the best commercially available

1 Proc. DOE Geothermal Program Review VIII, San Francisco, April 1990, p. 191, DOE Conf-9004131, Washington, D.C., 1990. 
coupling systems which will undergo complete disbondment from stainless steel upon exposure for 1 day in brine at $200^{\circ} \mathrm{C}$, copolymers made from the polyaromatic materials show no disbondment or loss of bond strength after 5 weeks. Additional work is required to improve the magnitude of the bond strength and to improve the thixotropic behavior of the adhesives in the liquid state.

Cost-shared efforts with operators at the Geysers to evaluate the use of polymer concrete and polymeric liners to mitigate corrosion were continued. Smal1 lined casing sections are being tested by the Coldwater Creek Operator Company and full-size collection piping tees by the Northern California Power Authority (NCPA). The results to date have been promising, and larger-scale tests are planned for FY 1992.

Without the successful completion of the above activities and others outlined in the FY 1992 AOP, the Level III Objectives for the Materials Development Project, and consequently the Level II Objectives for both the Conversion Technology and Hard Rock Penetration Tasks, will probably not be met.

\section{Objectives}

The Geothermal Materials Project is an important part of the Geothermal Division's (GD) Hydrothermal Category, and it has an impact on two tasks, Conversion Technology and Hard Rock Penetration. The objective of the project is to provide information to industry which will result in reduced costs of geothermal well-field and power-plant design, construction, and operation by (1) extending the operating range of equipment in terms of temperature limits and tolerance to chemically aggressive fluids, (2) extending equipment life, (3) reducing maintenance and replacement costs, and (4) substitution of lower cost materials. Specific goals to be achieved in realizing the objectives are to (1) reduce costs associated with lost circulation episodes by 30 percent in the near term, (2) reduce the costs of deep wells and directionally drilled wells by 10 percent in the near term, and (3) reduce well-cementing problems for typical hydrothermal wells by 20 percent in the near term.

If the GD program objectives are to be met, it is essential that new materials of construction be available. Advanced technology is required for industry to reduce costs caused by the severe geothermal environments encountered during drilling, well completion and test field development, heat extraction, power production, and reinjection of spent brine. Particular needs are for improved materials and methods to withstand 1) extremely high temperatures encountered in geothermal reservoirs and in energy conversion processes, and 2) severe corrosion and scaling by geothermal brines. Materials needs exist for specific components such as downhole drill motors, pumps, casing, packers, blow-out preventors, drillpipe protectors, rotating head seals, and heat exchangers. In particular, improvements in lost circulation control, lightweight well completion materials, hydrolytically stable chemical systems for bonding high temperature elastomers to steel substrates, and downhole drill motors, would significantly reduce well costs.

As a result of the small and uncertain geothermal market, industry will not develop the special materials required for these critical components. Therefore, the purpose of the BNL project is to provide the technical and managerial basis for the performance of high risk/high payoff materials R\&D so 
that the results are available to industry when they commence development of higher temperature and chemically aggressive geothermal resources.

\subsection{Category}

Level I Objective: Hydrothermal

Reduce the life-cycle cost of producing electricity from liquiddominated hydrothermal resources to $3-7$ cents/kWh by 1997 .

\subsection{Task: Conversion Technology}

Level II Objectives: Although the Materials Project is structured as a project within the Conversion Technology Task, it is also making major contributions to the Hard Rock Penetration Task. Future commercialization within the Geopressured-Geothermal, Hot Dry Rock, and Magma Categories will also be highly dependent upon materials development.

For the Conversion Technology Task, the Level II Objectives are as follows :

- For binary plants at reservoirs in the temperature range of $150^{\circ}$ to $200^{\circ} \mathrm{C}$, reduce typical cost of power by 8 to 20 percent through improvements in efficiency and in $O \& M$ cost components in the midterm.

- For flash plants, reduce typical cost of power by 2 to 6 percent through improvements in materials and auxiliary equipment related to scaling, corrosion, and other brine-handling requirements in the mid-term.

The Level II Objective for the Hard Rock Penetration Task is to reduce the life-cycle cost of hydrothermal electricity by 10 to 13 percent through improvements in fluid production and procedures in the mid-term.

\subsection{Project: Materials Development}

Level III Objectives of the Conversion Technology and Hard Rock Penetration Tasks being addressed by the Materials Development Project are as follows :

- Reduce costs associated with lost circulation episodes by 30 percent in the near-term.

- Reduce costs of deep wells and directionally drilled wells by 10 percent in the near-term.

- Reduce well cementing problems for typical hydrothermal wells by 20 percent in the near-term.

- Reduce the cost of mitigating $\mathrm{HCl}$-induced corrosion in wells and steam collection piping at the Geysers by the development of low. cost composite liner systems in the near-term. 
2.4 Activities: In FY 1991, the Materials Development Project was comprised of the six activities listed below. Expected accomplishments as documented in the FY 1991 Annual Operating Plan (AOP) or subsequently added, are also summarized.

\subsubsection{Advanced High Temperature Lightweight Cements}

- Identify best candidate cement

- Identify retarding admixtures

- Complete pumpability tests

- Perform long-term durability testing in autoclaves

- Complete downhole testing

- Peer-review publications

\subsubsection{Thermally Conductive Polymer Cement Liners}

- Initiate and complete field testing of heat exchanger No. 1

- Issue interim report for heat exchanger test No. 1

\subsubsection{Chemical Systems for Lost Circulation Control}

- Selection of material

- Complete mud displacement tests

2.4.4 Corrosion Mitigation at the Geysers

- Plan cost-shared test program with steam producers

- Complete preliminary tests to establish technical feasibility

2.4.5 High Temperature Chemical Coupling Systems

- Selection of promising bonding systems

- Identify metallic surface modification process

- Characterization of metal/bonding agent/elastomer interfaces

- Initiate long-term durability testing in autoclaves 


\subsubsection{Geothermal Drilling Organization Elastomer Activities}

- Liaison activities with GDO/SNL selected contractors

Without the successful completion of the above activities and others outlined in the FY 1992 AOP, the Level III Objectives for the Materials Development Project, and consequently the Level II Objectives for both the Conversion Technology and Hard Rock Penetration Tasks, will probably not be met. Advanced materials of construction represent the common denominator for all of these goals. For example, to reduce the cost of fluid production, a significant reduction in well drilling cost must be attained. To meet this goal, improved elastomers and methods for bonding them to reinforcing steel substrates are essential for use in tools such as drillpipe protectors, rotating head seals, blow-out-preventors and downhole drill motors. Costeffective methods for reducing corrosion in well casing are also needed.

Currently, the cost of correcting lost circulation problems occurring during well drilling and completion operations constitutes 20 to 30 percent of the cost of a well. One way to appreciably reduce this cost is to develop high temperature fast setting chemical systems which can be injected into the formation to seal the fissures without the necessity of removing the drillstring.

The development of lightweight $\mathrm{CO}_{2}$-resistant well cements will reduce the frequency of lost circulation episodes during well completion operations and will extend well life when $\mathrm{CO}_{2}$-rich aquifers are encountered.

Reductions in the corrosion rates and fouling coefficients in binary and flash plants will greatly improve the efficiency of these processes and help meet the Level II Objectives in the Conversion Technology Task.

3. Fiscal Year Accomplishments

3.1 Task: Conversion Technology

3.2 Project: Materials Development

3.3 Activity 1: Advanced High Temperature Lightweight Cements

The service life of a geothermal well is highly dependent upon the quality of the well cementing operation, and as drilling environments become more hostile, constraints resulting from the lack of high performance lightweight cements become more acute. Therefore, in order to meet the GD Programmatic Objectives of reducing well cementing problems for typical hydrothermal wells by 20 percent, improved well cements must be developed. The R\&D strategy seeks to improve the effectiveness of geothermal well completion procedures and to reduce the occurrence of lost circulation problems by the development of $\mathrm{CO}_{2}$-resistant lightweight high temperature cements. These improvements will help to transfer well-life limitations from materials to reservoir constraints in a cost effective manner. The work is being performed as a cooperative research effort with the New Zealand Department of Scientific 
Research (DSIR). BNL develops the cement formulations and performs physical, chemical and mechanical evaluations. DSIR is conducting downhole tests in wells at their Mokai and Rotokowa geothermal fields.

An ideal cement for geothermal well completions would have the following properties: 1) slurry density $<10 \mathrm{lb} / \mathrm{gal}, 2$ ) bulk density $<62.4$ $\mathrm{lb} / \mathrm{ft}^{3}, 3$ ) compressive strength at $24 \mathrm{hr}$ age $>1000$ psi, 4) permeability to water $<0.1 \mathrm{~m}$ Darcy, and 5) bond strength to steel casing $>10 \mathrm{psi}$. In addition, the slurry should be pumpable by API standards for $>4 \mathrm{hr}$ at $150^{\circ} \mathrm{C}$, be compatible with drilling mud, and after curing be resistant to carbonation and brine, and non-corrosive to steel casing. A cost of $<\$ 10 / \mathrm{bag}$ is also desired.

During FY 1991, work to formulate and test lightweight $\mathrm{CO}_{2}$ resistant cements continued. Plans to initiate a Cooperative Research and Development Agreement (CREDA) with a geothermal firm for work on lightweight cements were formulated, and review procedures by all parties are underway.

In FY 1990, phosphate modified calcium aluminate cements were identified as promising $\mathrm{CO}_{2}$-resistant binders for lightweight cements. This work was continued in FY 1991 and the results published in the Journal of the American Ceramic Society. The results from this study concluded that rapidsetting phosphate bonded cementitious materials which are not susceptible to hydrothermal-induced hydrolysis can be prepared by mixing at room temperature calcium aluminum cement and Poly-N fertilizer containing ammonium dihydrogen monobasic orthophosphate as the major phosphate component. After curing for 1 hr at room temperature, compressive strengths $>3,000$ psi are obtained. When cured in a hydrothermal environment at $200^{\circ} \mathrm{C}$ for $24 \mathrm{hr}$, compressive strengths $>10,000$ psi, 10 times greater than the American Petroleum Institute (API) criterion are achieved. At $300^{\circ} \mathrm{C}$, changes in the crystal size of the cement microstructure result in strength reductions to $-6,000 \mathrm{psi}$.

Laboratory testing to measure the rate of carbonation of the cements was performed and the results submitted to the Journal of Cement and Concrete Research for publication. The date from autoclave tests conducted in sodium carbonate-saturated brine at $300^{\circ} \mathrm{C}$ indicated that phosphate modified calcium aluminate cements retarded with borax to make them pumpable as defined by API standards, are $\sim 20$ times more resistant to carbonation than class $H$ cement and twice as resistant as unmodified calcium aluminate cements. The cements are pumpable for $4 \mathrm{hr}$ at $150^{\circ} \mathrm{C}$.

Downhole testing of BNL-supplied cements being performed as a cost-shared cooperative effort with the Department of Scientific and Industrial Research (DSIR) in New Zealand was continued throughout the year but it has not been possible to retrieve any of the samples for evaluation due to a partial collapse of the well casing as a result of corrosion. This problem makes it extremely unlikely that any additional data will be accrued from the current test series. Attempts to locate alternative downhole test capabilities are now underway. Possibilities being considered include establishing a Cooperative Research and Development Agreement (CREDA) with industry.

Planned FY 1991 milestones for this activity are listed in Section 2.4.1. Milestones $1-4$ and 6 were attained but work is continuing in each of these areas in order to make further improvements. Milestone 5 (Downhole 
Testing at DSIR) cannot be met due to a well casing collapse which makes it impossible to remove the test specimens.

$$
\text { in is }
$$

During FY 1991, spending for this activity amounted to $\$ 200 \mathrm{~K}$. A total of 1.25 man-years of scientific and professional labor was committed to the work. The work on 1 ightweight $\mathrm{CO}_{2}$-resistant cements for $300^{\circ} \mathrm{C}$ hydrothermal well completions is on schedule and the technology transfer process to industry should be started by the end of FY 1992 with utilization of a CREDA.

\section{Activity 2: Thermally Conductive Polymer Cement Liners}

One of the Level III Goals of the Conversion Technology Task is to reduce the cost of binary power cycles by development of low cost corrosion and scale resistant materials of construction for heat exchanger tubing. This activity investigates the use of thermally conductive composites for this application.

Corrosion of the brine side of tubing in shell and tube heat exchangers can be a major problem in binary plants unless a very expensive high alloy steel (AL-29-4C) is used. Even then, excessive fouling prevents the economic use of binary processes with hypersaline brine reservoirs. Both problems could possibly be solved with the development of thermally conductive corrosion and scale resistant polymer concrete liners for steel tubing. The work consists of determinations of the effects of composition and processing variables on the thermal and scale-resistance characteristics of the composite, and measurements of the physical and mechanical properties after exposure to hot brine under laboratory and field conditions.

The planned milestones for FY 1991 are given in Section 2.4.2. Milestone 1 was completed and the second is underway.

After completion of "base line" testing at the Geothermal Test Facility (GTF) by Idaho National Engineering Laboratory (INEL) personnel, the prototype shell and tube heat exchanger containing $80 \mathrm{ft}$ of thermally conductive polymer concrete lined carbon steel tubing (PCL) was assembled and placed in test at the Del Ranch geothermal power plant operated by Red Hill Geothermal. The fluid used in the test was at a temperature of $183^{\circ} \mathrm{C}$ and had a salt content of $-275,000 \mathrm{ppm}$. Under heat exchange operations, its scaling and silica deposition rate was estimated to be 5 in./yr.

Considerable difficulty was encountered when attempts were made to operate the PCL heat exchanger and a conventional high alloy steel (AL-6XN) tubed unit over an extended period of time at the Del Ranch power plant. These difficulties were due to the service handling problems associated with the brine at this facility, in particular; its supersaturation with silica.

Preliminary examination of the data indicated that the high alloy steel tube fouled to the point where the overall thermal resistance approximately doubled during $-250 \mathrm{hr}$ of operation. Most, if not all of this increase was attributed to fouling on the brine side of the tubing since little fouling on the cold water side of the AL-6XN tubes was detected.

The data from the test loop containing the PCL tubes also indicated a doubling of the thermal resistance during a similar operating time. 
However, appreciable amounts of scale were detected on the outside (cooling water side) of the PCL carbon steel tubes. Therefore, the degree of fouling on the PC surface was less than that on the high alloy controls, but the differences were not quantifiable.

Due to the very labor intensive effort required to install and operate the flow tests, and the scaling problems which prevent long term steady-state operation, INEL recommended to DOE/IDO that the experiment be terminated. ${ }^{2}$ This recommendation was approved, and the unit disassembled. The PCL tubing was cut into sections and returned to BNL in October 1991 for examination. When these examinations are completed in FY 1992, a joint INEL/BNL final report will be prepared. This report will summarize the thermal and hydraulic performance results from testing at the GTF, and the results of the testing at the $\mathrm{Del}$ Ranch plant. The latter will include the results from the post test examinations, and a review of the thermal performance of the tubes. During FY 1991, spending for this activity amounted to $\$ 70 \mathrm{~K}$. A total of 0.43 man-years of scientific and professional labor was committed to the work.

\section{Activity 3: Chemical Systems for Lost Circulation Control}

Currently, the cost of correcting lost circulation problems occurring during well drilling and completion operations constitutes 20 to 30 percent of the cost of a well. The GD Level III Objective is to reduce well drilling costs for typical hydrothermal wells by 10 percent in the near term. Analyses indicate that significant cost reductions can be made if advanced high temperature chemical formulations which, depending upon the fissure size, can be used with or without particulate fillers to rapidly plug lost circulation zones. The greatest cost reduction can be attained if it is not necessary to remove the drillbit during the repair operation. In this case, potential cost savings compared to the costs for conventional two-plug cement treatments range from 47 to $78 \%$.

The objective of this project activity is to develop advanced cementitious materials that meet the following criteria: 1) pumpability (viscosity $<70 \mathrm{BC}$ ) for up to $4 \mathrm{hr}$ at temperatures up to $200^{\circ} \mathrm{C}$, 2) curing times up to $4 \mathrm{hr}$ at formation temperatures up to $300^{\circ} \mathrm{C}, 3$ ) compressive strength at $2 \mathrm{hr}$ age $>500$ psi, 4) permeability $<10^{-1}$ Darcy, and material cost $<\$ 10 / \mathrm{bag}$. In addition, the cementitious material must be compatible with a variety of particulate filler systems, have a reasonable storage life, be environmentally benign, and be capable of placement by use of conventional or slightly modified techniques.

During FY 1991, R\&D work was continued as a cooperative effort with Sandia National Laboratories (SNL). Experiments were performed with a previously identified bentonite-ammonium polyphosphate-borax-magnesium oxide system to determine methods for controlling the curing rates and, therefore, pumpability. For placement at temperatures $>60^{\circ} \mathrm{C}$, microencapsulation of the magnesium oxide in organics was determined to be an effective method for controlling pumpability. The formulations are being optimized with respect to

$\overline{{ }^{2} \text { Letter, G. }}$ L. Mines (INEL) to K. J. Taylor (DOE/IDO), August 26, 1991. 
placement and formation temperatures and the resultant mechanical properties of the cured cements.

Exploratory experiments were started with three other cement systems: $\mathrm{CaO} \cdot \mathrm{Al}_{2} \mathrm{O}_{3}$-bentonite-ammonium phosphate-borax, $\mathrm{CaO} \cdot \mathrm{Al}_{2} \mathrm{O}_{3}-\mathrm{CaO}\left(\mathrm{Al}_{2} \mathrm{O}_{3}\right)_{2}-$ bentonite-ammonium phosphate-borax, and class $\mathrm{H}$ cement-bentonite. In FY 1992 the most promising formulations from these systems will be selected for optimization with respect to various placement methods and formation conditions. If successful, commercial suppliers and users of the advanced materials will then have a choice of one or more formulations which can be selected on the basis of existing field conditions and cost.

Six potential methods for placement of the advanced chemical systems into fractured zones have been identified by SNL. These are listed below: (1) pumped through open drillpipe, (2) pumped through drillable straddle packer, (3) pumped through bit using encapsulated accelerator, (4) pumped through bit using downhole injector, (5) pumped through wirelinedeployed porous packer, and (6) pumped through drillstring - deployed porous packer. For each of these methods the pumpability requirements, material quantities, setting times, and operating temperatures were estimated and these needs are being matched with the laboratory identified materials characteristics. Advanced high temperature MgO-based rapid setting materials suitable for placement using methods 1,2 , and 6 appear to be ready for demonstration today. Materials for use with methods $3-5$ require additional optimization in FY 1992, but should be ready for prototype testing late in FY 1992 or in FY 1993 .

Planned FY 1991 milestones for this activity are listed in Section 2.4.3. Milestone No. 1 was completed although work to optimize the formulation for use with the six potential placement techniques listed above is continuing. Exploratory work with other candidate formulations is also underway. Mud displacement tests (milestone No. 2) were performed in small-scale laboratory equipment, and larger scale testing will be performed in conjunction with SNL in FY 1992.

The FY 1991 budget for this activity was $\$ 170 \mathrm{~K}$. A total of 1.08 man-years of scientific, professional and technical staff time was committed to the activity.

\section{Activity 4: Corrosion Mitigation at the Geysers}

Increased $\mathrm{HCl}$ concentrations in the steam produced from geothermal wells at the Geysers have resulted in severe corrosion problems in the upper regions of the well casing where some condensation occurs, and in the steam collection piping. In some cases this has resulted in the shutdown of wells causing reduced steam supply and, therefore, decreases in electric power generation. Increased operating costs and safety and environmental concerns have also resulted.

Cooperative cost-shared work performed at the Geysers with the Coldwater Creek Operator Company at the Northern California Power Authority (NCPA) continued throughout the report period. Based upon the results from tests conducted by Coldwater Creek Operator Company in late FY 1990 which 
indicated that polymer cement ( $P C$ ) composite systems can provide corrosion protection to geothermal well casing upon exposure to condensing acidified steam environments, a series of laboratory tests were performed to optimize the system with respect to the exposure conditions. In this work which was completed in FY 1991, several series of test samples were exposed in autoclaves to $\mathrm{pH} 2 \mathrm{HCl}$ solutions at $90^{\circ} \mathrm{C}$ for $3 \mathrm{mo}$. and to $\mathrm{pH} 2 \mathrm{HCl}$ acidified steam at $200^{\circ} \mathrm{C}$ for $6 \mathrm{mo}$. Two monomer formulations and two filler systems were evaluated. The monomer formulations were a styrene-trimethylolpropane trimethacrylate (TMPTMA) system and a vinyl ester resin-TMPTMA system. The two filler systems had the same general mix design, however, one system contained Type III portland cement and the other contained class $\mathrm{H}$ well cement. The general formulation of the PC mixes was a follows: 14 to 16 wto monomer, 86 to $84 \mathrm{wt}$ blended fine aggregate. In general, the blended aggregate system consisted of graded silica sand and cement. The results from both the acid and steam exposures indicated that all four systems performed well, exhibiting little or no deterioration and minimal loss of strength.

Concurrent with the above work, the effectiveness of polyphenylene sulfide (PPS) polymer as an acid resistant coating when applied to mild steel surfaces containing a polyacrylicacid-modified zinc phosphate conversion coating as a bonding agent, was also evaluated. After 3 mo. autoclave exposure to $\mathrm{pH} 2 \mathrm{HCl}$ at $90^{\circ} \mathrm{C}$, this system also displayed good durability.

Based upon these promising results, field tests were resumed at the Coldwater Creek Operator Company site at the Geysers. The effort involved the testing of several 1-in. diam by 7.5 in. long carbon steel nipples which were lined at BNL and then sent to the facility for testing. Two PC liners were tested; one was a TMPTMA system made with Type III portland cement and the other was styrene-TMPTMA system made with class $\mathrm{H}$ well cement. The PPS coating was also tested. The nipples were tested by inserting them into the well head fluid stream perpendicular to the flow. The temperature of the stream was approximately $177^{\circ} \mathrm{C}$ and the velocity was about $200 \mathrm{ft} / \mathrm{sec}$. The nipples were subjected to occasional abrasive attack resulting from particular matter within the stream. The nipples were returned to BNL for detailed evaluation in FY 1992. Preliminary visual inspections indicated little if any erosion or chemical attack on the PC samples. The PPS-lined nipples contained regions where the polymer had been removed, probably due to abrasion by particulates in the steam.

Additional field tests were planned for FY 1992. The first series will consist of four lined 8 -in. diam. by 12 -in. long wellhead sections. Two will be lined with a PC selected on the basis of FY 1991 results, the others with PPS. These tests will commence in the second quarter of FY 1992.

Contingent upon the results from the work described above and other candidate techniques under investigation by Coldwater, and the continued financial viability of the Company, several 10 to $12 \mathrm{ft}$ lengths of 16 -in. diam well casing will be lined and installed at the top portion of their wells. This work is expected to be performed in FY 1992. If so, the work will then be expanded to include the installation of lined casing to depths of several hundred feet. 
The field tests initiated at the NCPA facility involve the testing of two 12-in. diam "T" sections which were lined with $\mathrm{PC}$ at BNL and then send to the facility for testing. Both " $T$ " sections were lined with a $3 / 16-$ in. thick PC made with the styrene-TMPTMA system containing the Type III portland cement. One of the liners also contained 1/4-in. long graphite fibers. The fibers were added to the system in an attempt to control shrinkage cracking of the liner mix. To date, NCPA has installed the sections.

The FY 1991 budget for this activity was $\$ 100 \mathrm{~K}$. A total of 0.62 man-years of scientific, professional and technical staff time was committed to the activity.

\section{Activity 5: High Temperature Chemical Coupling Systems}

As indicated below in Activity 6 "Geothermal Drilling Organization Elastomer Activities", BNL provides liaison services to Sandia National Laboratories (SNL) and the Geothermal Drilling Organization (GDO) in order to enhance the transfer of completed GD-sponsored high temperature elastomer technology to industry so that it can be utilized in equipment needed by the GDO member companies. In the course of this work, it was determined that the unavailability of a hydrolytically stable chemical coupling system needed to bond high temperature elastomers to metal reinforcement prevented the successful development of a drillpipe protector which would meet GDO specification. The development of advanced blow-out-preventors and Moineau stators for downhole pump applications is expected to be impacted similarly.

As a result of this materials constraint, BNL initiated work in FY 1991 to develop advanced coupling systems. The work was separated into three elements: a) elemental alteration and transformation of zinc-phosphate crystal coatings for use as high temperature protective coatings on steel and to enhance bonding with the coupling system, b) coupling adhesives which produce hydrothermally stable polymer-metal interfaces, and c) characteristics of polymer-elastomer interfaces after exposure to hydrothermal environments. Work in each element was performed concurrently.

Two polyaromatic-type adhesives, polyphenyletheretherketone (PEEK) and polyphenylethersulfone (PES) and copolymers made from mixtures of the polymers were selected for initial studies. The melting points of these polymers are $345^{\circ}$ and $285^{\circ} \mathrm{C}$, respectively, and they form high strength acid resis tant adhesives.

Specimens which consisted of Y267 EPDM elastomer bonded to stainless steel using PEEK exhibited peel strengths ranging between 5 and 14 $\mathrm{lb} / \mathrm{in}^{2}$. These values were promising, but 3 to 8 times lower than that needed for drillpipe protectors. Failure normally occurred at the elastomer-adhesive interface. Curing of the elastomer under the conditions generally used by the elastomer industry may improve this bonding. More importantly, compared to the best commercially available bonding system which upon exposure to brine at $200^{\circ} \mathrm{C}$ for 1 day will undergo complete disbondment from stainless steel, bonding systems composed of copolymers made from PEEK-PES mixtures undergo no disbondment or loss of bond strength after 5 weeks. For drillpipe protectors, stability for a minimum of $48 \mathrm{hr}$ is desired. 
BNL is currently attempting to increase the magnitude of the bond between the coupling adhesives and the metal substrate by chemically modifying the metal surface. Increases in both physical and chemical bonding are desired. Recent tests have given extremely promising results. It has been found that the application of a 1 to 2 micron thick polyelectrolyte-modified zinc phosphate conversion coating to the steel prior to the application of the coupling system increases the bond strength by $-30 \%$. More importantly, upon exposure to high temperature low pH acid environments or electrochemical attack, both of which will result in rapid deterioration, the surface modified-coupling system interface remains stable. The measured delamination rate was -150 times lower than that of the coupling agent-steel control. This work is continuing.

Planned FY 1991 milestones for this activity are listed in Section 2.4.5. Preliminary results are available for each of these topics and the data are being compiled in a paper which will be submitted to a peer-reviewed publication in FY 1992. R\&D efforts are continuing with the goal of further improving the bond strength values.

The FY 1991 budget for this activity was $\$ 160 \mathrm{~K}$. A total of 0.99 man-years of scientific and professional staff time was committed to the activity.

\section{Activity 6: Geothermal Drilling Organization Elastomer Activities}

BNL provides liaison services to SNL and the Geothermal Drilling Organization (GDO) in order to enhance the transfer of completed GD-sponsored high temperature elastomer technology to industry so that it can be utilized in equipment needed by the GDO. Such needs include drillpipe protectors, rotary head seals, blow-out protectors, and Moineau stators for downhole drillmotors.

Work on the development of advanced high temperature drillpipe protectors was essentially completed by the GDO selected contractor, Regal International. Based upon laboratory and field testing conducted in FY 1989, and a FY 1990 field test, it was concluded that the unavailability of a hydrothermally stable chemical coupling system needed to bond the elastomers to steel reinforcement, prevented the development of a tool which met the GDO requirements. Regal prepared a draft final report which was reviewed by BNL and SNL. Finalization is in progress. Based upon the conclusions, work to develop advanced coupling systems was started as part of the Geothermal Materials Development Project. Accomplishments in FY 1991 were summarized above in Activity 5 .

Development of advanced rotary head seals was continued by A-Z Grant International under contract with the GDO. In FY 1990, two promising elastomers and a bonding system were identified and laboratory tested, a sealing configuration designed, and full-scale seal units fabricated. Field testing at GDO sponsor test sites at the Geysers and Imperial Valley was scheduled for FY 1991. Contractural uncertainties due to the withdrawal of one of the two GDO participants in this effort resulted in the delay of these tests. It is not certain when these tests will be conducted. During the year A-Z Grant 
fabricated and field tested seals using corporate funds, and they are advertising the commercial availability of advanced rotary head seals.

Funding ( $\$ 8 \mathrm{~K}$ ) to cover the BNL liaison activities was provided by SNL. A total of 0.07 man-years of scientific manpower was committed to the activity.

\section{Activity 7: Technology Transfer}

Several linkages with private industry were established to transfer the technology developed in the Geothermal Materials Development Project. Funded full-cost recovery programs at BNL for the following applications were implemented.

\section{Organization}

Gas Research Institute

Consolidated Edison Co. of New York

Long Island Lighting Company $\underline{\text { Topic }}$

Condensing heat exchangers for high efficiency gas furnaces

Utility vaults for steam district-heating systems

Corrosion resistant coatings for heat exchange applications

Negotiations with a leading geothermal energy producer for estab-

lishing a Cooperative Research and Development Agreement (CREDA) titled

"Advanced Cements for Geothermal Well Completions", were also initiated.

4. Management

4.1 Organization

The technical and administrative management of the R\&D phases of this project are under the direction of BNL with project policy established by the GD Task Manager, Raymond LaSala.

Fiscal control by BNL is exercised in the form of monthly comparisons, over the project term, of actual costs incurred against corresponding line items of the budget. Technical results are monitored through a periodic review, by the Contractor Project Manager, of accomplishments by measuring actual performance with generally accepted standards for R\&D and other investigative or analytic procedures, as observed by universities and large independent research facilities including. BNL.

\subsection{Management Structure}

The GD Manager of the Geothermal Materials Project is Raymond LaSala (FTS 896-4198). Field level program monitoring is provided by the Idaho Falls Operations office. Field level management is by the Contractor Work Proposal Managers at BNL, Leon Petrakis, Chairman, Department of Applied Science (FTS 666-3037) and John Andrews, Head, Energy Efficiency and Conservation Division 
(FTS 666 7726). The Principal Investigator at BNL is Lawrence E. Kukacka, Leader, Process Materials Group (FTS 666-3065).

\subsection{Work Breakdown Structure}

Task Management: R. LaSala, DOE-HQ

Project Management: K. Taylor DOE-IDO in FY 1991, currently open Principal Investigator: L.E. Kukacka, BNL

Cements: T. Sugama

Thermally Conductive Composites: L. E. Kukacka

Lost Circulation Control: M. Allan

Corrosion Mitigation: R. Webster

Elastomers/Metal Bonding: M. Miura

GDO Elastomer Activities: L. E. Kukacka

4.4 Interfaces/Contacts

National Laboratories

Conversion Technology Task, G. Mines, INEL

Hard Rock Penetration, J. Dunn, SNL

Geothermal Drilling Organization

J. Dunn, SNL

R. Wemple, SNL

S. Pye, Unocal

T. Bailey, A-Z Grant/Drilex

T. Thomerson, Regal International

Geysers Support

R. Fossa, Coldwater Creek Operator Co.

S. Enedy, NCPA

T. MacPhee, Unocal

W. C. Allen, Unocal

\subsection{Meetings/Reviews}

DOE/GD Conversion Technology Program Review, Washington, D.C., December 12, 1990.

Sixteenth Annual Workshop on Geothermal Reservoir Engineering, Stanford University, January 23-25, 1991.

DOE Geothermal Program Review 1X, San Francisco, CA, March 19-21, 1991. 


\section{Reports}

The following peer-reviewed publications and technical reports were prepared and/or issued during FY 1991:

Kukacka, L. E. Geothermal materials development, FY 1990 accomplishments and current activities. BNL 45995, Proc. DOE Geothermal Program ReviewIX, San Francisco, March 1991, pp 71-75, DOE Conf-913105, Washington, D.C., 1991.

Sugama, T. and Carciello, N. R. Strength development in phosphate bonded calcium aluminate cements. BNL 46263, J. Am. Ceramics Soc., 75,5 , 1023-30 (1991).

Sugama, T. and Carciello, N. R. Interfaces of polyphenylene sulphideto-metal joints. BNL 46138, Int. J. Adhesion and Adhesives, 11, 2, 97-104, April 1991.

Sugama, T. and Pak, J. Characteristics of transition metal-adsorbed anhydrous zinc phosphate coatings as corrosion barriers for steels. BNL 45248, Mat. and Manufacturing Proc., 6, 2, 227-239 (1991).

Sugama, T., Gray, G., and Carciello, N. R. Influence of set-retarding admixtures on alkali carbonation of calcium aluminate cements under hydrothermal conditions. J. Mat. Sci. and Tech., in press.

Sugama, T., Gray, G., and Carciello, N. R. The interface between zinc phosphate-deposited steel fibers and cement paste. BNL 44759, J. Mat. Sci., in press.

Sugama, T. and Carciello, N. R. Carbonation of hydrothermally treated phosphate-bonded calcium aluminate cements. Cem. and Conc. Res., in press.

Kukacka, L. E. Geothermal materials development, annual report, FY 1990. BNL 45998, February 1991.

Kukacka, L. E. Geothermal materials project input for conversion technology task, annual operating plan, FY 1992. BNL 46274, August 1991. 